\title{
A chiral analog of the bicyclic guanidine TBD: synthesis, structure and Brønsted base catalysis
}

\author{
Mariano Goldberg ${ }^{1}$, Denis Sartakov ${ }^{1}$, Jan W. Bats ${ }^{1}$, Michael Bolte ${ }^{2}$ \\ and Michael W. Göbel ${ }^{* 1}$
}

\author{
Full Research Paper \\ Address: \\ ${ }^{1}$ Institute for Organic Chemistry and Chemical Biology, Goethe \\ University Frankfurt, Max-von-Laue-Straße 7, D-60438 Frankfurt am \\ Main, Germany and ${ }^{2}$ Institute for Inorganic and Analytical Chemistry, \\ Goethe University Frankfurt, Max-von-Laue-Straße 7, D-60438 \\ Frankfurt am Main, Germany \\ Email: \\ Michael W. Göbel - m.goebel@chemie.uni-frankfurt.de \\ ${ }^{*}$ Corresponding author \\ Keywords: \\ absolute configuration; anthrone; cycloaddition; kinetic resolution; \\ lipase
}

Beilstein J. Org. Chem. 2016, 12, 1870-1876. doi:10.3762/bjoc.12.176

Received: 01 June 2016 Accepted: 03 August 2016 Published: 19 August 2016

Associate Editor: M. Rueping

(C) 2016 Goldberg et al.; licensee Beilstein-Institut. License and terms: see end of document.

\begin{abstract}
Starting from (S)- $\beta$-phenylalanine, easily accessible by lipase-catalyzed kinetic resolution, a chiral triamine was assembled by a reductive amination and finally cyclized to form the title compound 10. In the crystals of the guanidinium benzoate salt the six membered rings of $\mathbf{1 0}$ adopt conformations close to an envelope with the phenyl substituents in pseudo-axial positions. The unprotonated guanidine 10 catalyzes Diels-Alder reactions of anthrones and maleimides (25-30\% ee). It also promotes as a strong Brønsted base the retro-aldol reaction of some cycloadducts with kinetic resolution of the enantiomers. In three cases, the retroaldol products ( $48-83 \%$ ee) could be recrystallized to high enantiopurity ( $\geq 95 \%$ ee). The absolute configuration of several compounds is supported by anomalous X-ray diffraction and by chemical correlation.
\end{abstract}

\section{Introduction}

In guanidinium ions charge delocalization is an important factor to stabilize the protonated form. As a result, guanidines are exceptionally strong nitrogen bases. As part of the amino acid arginine, they play an important role in biochemistry, mainly by forming ion pairs. In addition, numerous guanidine derivatives with complex cyclic structures can be found in natural products [1]. Simple guanidines such as tetramethylguanidine have been used as strong Brønsted bases in countless applications [2,3].
The bicylic guanidine 1,5,7-triazabicyclo[4.4.0]dec-5-ene (TBD, 1, Figure 1) [4], another important Brønsted base in preparative chemistry, may also act as a powerful nucleophilic catalyst [3]. Substituted analogs of TBD [5], such as the chiral compound 2, have become popular in the field of molecular recognition, however, without being tested as catalysts [5-10]. A first example of enantioselective Michael addition has been reported for guanidine $\mathbf{3}$, albeit with low selectivity [11]. Com- 
<smiles>C1CN=C2NCCCN2C1</smiles><smiles>OCC1CCN2CCC(CO)NC2=N1</smiles><smiles>c1ccc(C(c2ccccc2)C2CCN3CCC(C(c4ccccc4)c4ccccc4)NC3=N2)cc1</smiles>

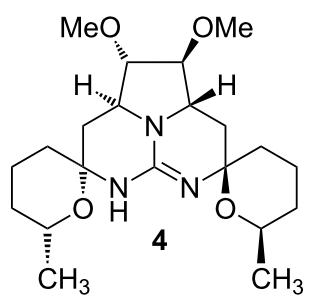<smiles>OC1CC2CC(Cc3ccccc3)NC3=NC(Cc4ccccc4)CC1N32</smiles><smiles>C1CCC(C2CN3C[C@@H](C4CCCCC4)N=C3N2)CC1</smiles><smiles>[3H]N1C2=N[C@@H](c3ccccc3)CN2C[C@H]1c1ccccc1</smiles><smiles>Br[C@H]1CN2C[C@@H](Br)NC2=N1</smiles><smiles>CC(C)(C)C1CN2C[C@@H](C(C)(C)C)C=NN1C2</smiles><smiles>c1ccc([C@H]2CCN3CC[C@H](c4ccccc4)NC3=N2)cc1</smiles>

Figure 1: Structure of guanidines 1-10.

pounds $\mathbf{4}$ and 5, inspired by the structure of ptilomycalin A and related natural products, have been used as chiral phase-transfer catalysts $[12,13]$.

Bicyclic guanidines with five-membered rings are also known from the alkaloid isoalchornein [14,15]. In subsequent years, synthetic compounds (6-9) of this structural type have been developed as chiral Brønsted bases [16-19] and used for highly enantioselective Strecker [17] and Diels-Alder reactions [19].

Compared to guanidine $\mathbf{7}$ ring expansion into structure $\mathbf{1 0}$ would shift the stereogenic phenyl groups into closer proximity to a hydrogen-bonded guest molecule and thereby might improve the enantioselective control exerted by $\mathbf{1 0}$ when used as a catalyst. In this article we describe the synthesis of guanidine 10 together with some initial applications as a chiral Brønsted base.

\section{Results and Discussion}

Previous syntheses of bicylic guanidines $\mathbf{2}$ and 6-9 started from enantiomerically pure $\alpha$-amino acids $[6,8,10,16,17]$ or from their reduction products, chiral $\alpha$-amino alcohols $[9,18]$. In contrast, our approach used the racemic ester rac-12 of $\beta$-phenylalanine, easily accessible in a Knoevenagel-type condensation of benzaldehyde 11, ammonium acetate and malonic acid, followed by esterification (Scheme 1) [20,21]. A kinetic resolution of the enantiomers was achieved by enzymatic hydrolysis with Amano lipase PS from Burkholderia cepacia $[22,23]$, a method already optimized for technical use [24]. The best results were obtained with methyl tert-butyl ether as a cosolvent [24]. By simple precipitation, batches larger than $15 \mathrm{~g}$ of the $S$-configurated acid $\mathbf{1 3}$ could be isolated in $90 \%$ yield ( $45 \%$ based on rac-12). In a two-step procedure 13 was converted into amino alcohol $\mathbf{1 4}$ without recrystallization in order to keep the enantiomeric excess unchanged. It was determined at this stage to be better than $99 \%$. The $S$-configuration was assigned to $\mathbf{1 3}$ in accord with published data [22-24]. Intermediate 14 was converted into amine 16 by mesylation (79\%), reaction with $\mathrm{NaN}_{3}(96 \%)$ and hydrogenation (84\%). Aldehyde 17, also accessible from 14 by oxidation ( $87 \%$ ), then could be coupled with amine $\mathbf{1 6}$ in a reductive amination to form $\mathbf{1 8}$ (58\%). After removal of the Boc protecting group (quant.), triamine 19 was reacted with dimethyl trithiocarbonate in refluxing nitromethane. The thiourea intermediate was activated in situ by $S$-alkylation with MeI. Upon further heating the final cyclization occured forming the iodide salt 10 a of $S, S$ configurated guanidine $10(67 \%)$. The free base could be isolated by extraction with $\mathrm{CH}_{2} \mathrm{Cl}_{2}$ from $20 \mathrm{M}$ aqueous $\mathrm{NaOH}$ (95\%). For experimental details see Supporting Information File 1.

A crystal structure could be obtained from the benzoate salt of 10 (Figure 2). The asymmetric unit contains two cations, two benzoate anions and ethyl acetate as a solvate molecule. Each 
<smiles>CCCOC(=O)C[C@H](N)c1ccccc1</smiles><smiles>NCC[C@H](NC(=O)OCc1ccccc1)c1ccccc1</smiles>

16<smiles>[Y][Y]([Y])([H])[H]</smiles>

18<smiles>N[C@@H](CCNCC[C@H](N)c1ccccc1)c1ccccc1</smiles>

19<smiles>N#CC[C@H](NC(=O)OCc1ccccc1)c1ccccc1</smiles>

15<smiles>CC(C)(C)OC(=O)N[C@@H](CCO)c1ccccc1</smiles>

14<smiles></smiles><smiles>O=CC[C@H](NC(=O)OCc1ccccc1)c1ccccc1</smiles>

17

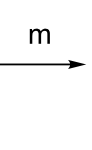

10

Scheme 1: Synthesis of guanidine 10. Conditions: (a) 1 equiv $\mathrm{HOOC}-\mathrm{CH}_{2}-\mathrm{COOH}, 2$ equiv $\mathrm{NH}_{4} \mathrm{OAc}, \mathrm{EtOH}, 78{ }^{\circ} \mathrm{C}, 5 \mathrm{~h}, 38 \%$; (b) 10 equiv $n$-PrOH, 1.5 equiv $\mathrm{H}_{2} \mathrm{SO}_{4}, 97^{\circ} \mathrm{C}, 4 \mathrm{~h}, 82 \%$; (c) Amano-Lipase PS (from Burkholderia cepacia), aqueous $\mathrm{Na}_{2} \mathrm{HPO}_{4}$ buffer, pH $7.00,50{ }^{\circ} \mathrm{C}, 1 \mathrm{~h}, \mathrm{~m}^{\circ}$ methyl tert-butyl ether, $50{ }^{\circ} \mathrm{C}, 24 \mathrm{~h}, 90 \%$ (45\% based on rac-12), >99\% ee; (d) 2.5 equiv $\mathrm{NaBH}_{4}, 1.2$ equiv $\mathrm{I}_{2}, \mathrm{THF}, 66{ }^{\circ} \mathrm{C}, 18 \mathrm{~h}, 86 \%$; (e) 1 equiv Boc $2 \mathrm{O}, 1.2$ equiv triethylamine, $\mathrm{CH}_{2} \mathrm{Cl}_{2}, 0{ }^{\circ} \mathrm{C}, 3 \mathrm{~h}, 100 \%$; (f) 1.1 equiv $\mathrm{MsCl}, 1.1$ equiv triethylamine, $\mathrm{CH}_{2} \mathrm{Cl}_{2}, 0{ }^{\circ} \mathrm{C}, 3 \mathrm{~h}, 79 \%$; (g) 3 equiv NaN 3 , DMF, $24{ }^{\circ} \mathrm{C}, 120 \mathrm{~h}, 96 \%$; (h) 2 equiv $\mathrm{SO}_{3}{ }^{*} \mathrm{Py}, 2.3$ equiv pyridine, 4.1 equiv triethylamine, DMSO, $\mathrm{CH}_{2} \mathrm{Cl}_{2}, 0{ }^{\circ} \mathrm{C}, 10 \mathrm{~min}, 24{ }^{\circ} \mathrm{C}, 2 \mathrm{~h}, 87 \%$; (i) $\mathrm{H}_{2}, \mathrm{Pd} / \mathrm{C}, \mathrm{MeOH}$, overnight, $84 \%$; (k) 1 equiv 17, THF, $48 \mathrm{~h}, 2$ equiv $\mathrm{NaBH}_{4}$; $\mathrm{MeOH}, 96 \mathrm{~h}, 58 \%$; (I) 10 equiv TFA, $\mathrm{CH}_{2} \mathrm{Cl}_{2}, 40{ }^{\circ} \mathrm{C}, 24 \mathrm{~h}, 100 \%$; (m) 1.3 equiv dimethyl trithiocarbonate, $\mathrm{MeNO}_{2}, 101^{\circ} \mathrm{C}, 2 \mathrm{~h}, 4$ equiv $\mathrm{AcOH}, 2$ equiv Mel, $101{ }^{\circ} \mathrm{C}, 3 \mathrm{~h}, 67 \%$ as iodide salt $10 \mathrm{a}$.

cation is connected by two $\mathrm{N}-\mathrm{H} \cdots \mathrm{O}$ hydrogen bonds to benzoate ions. The rings of cation $\mathbf{1 0}$ adopt a conformation close to an envelope with the phenyl substituents in pseudoaxial positions. The ion pairs and the solvate molecule are also connected by a number of very weak intermolecular $\mathrm{C}-\mathrm{H} \cdots \pi$ (phenyl) and $\mathrm{C}-\mathrm{H} \cdots \mathrm{O}$ contacts (see Supporting Information File 2).

The chiral guanidine $\mathbf{1 0}$ was tested as a Brønsted base catalyst to promote the reaction of anthrones $\mathbf{2 0}$ or $\mathbf{2 1}$ with maleimides 22-24 (Scheme 2) [19,25-28]. Depending on the substituents and the strength of the Brønsted base either Diels-Alder adducts or Michael products may be formed. Weaker bases such as ion-free bisoxazolines [28] or triethylamine are known to induce Diels-Alder adducts selectively whereas strongly basic guanidines such as $\mathbf{8}$ may also form the Michael products [19] which are the dominant products in polar solvents [25]. Previous mechanistic studies by Koerner and Rickborn [25] have collected strong arguments for a fast concerted

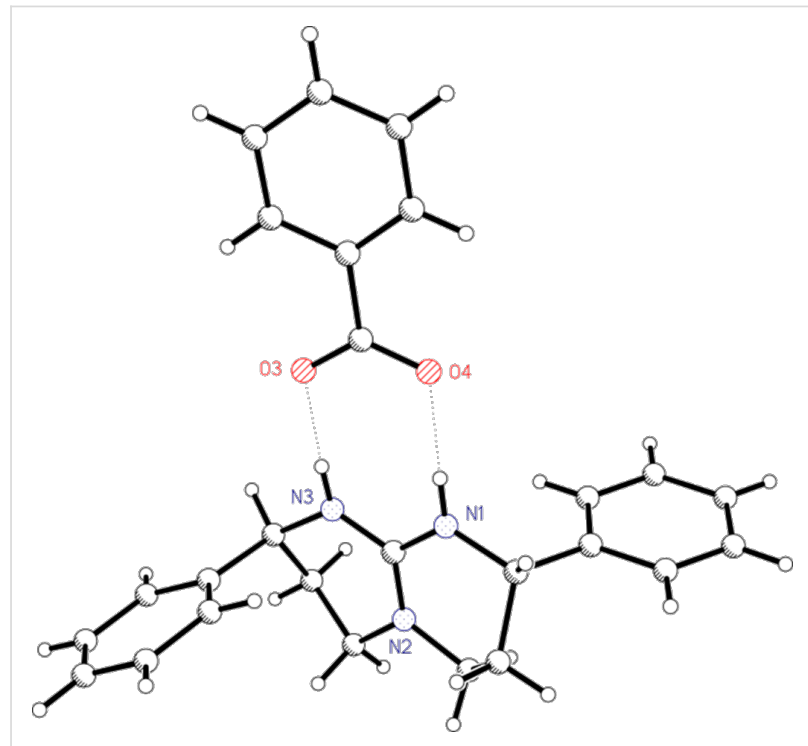

Figure 2: Crystal structure of guanidine 10 as a benzoate salt. Only one of the ion pairs is shown for the sake of clarity. 


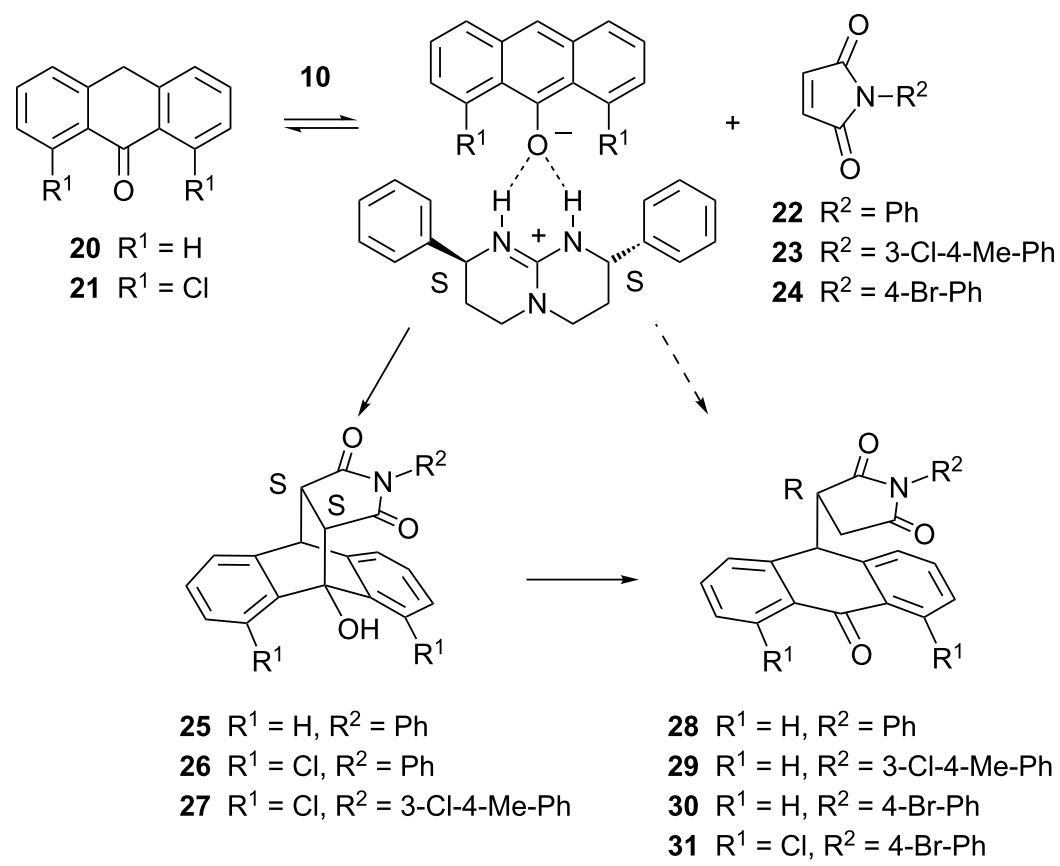

Scheme 2: Reaction of anthrones and $\mathrm{N}$-arylmaleimides catalyzed by guanidine $\mathbf{1 0}$. The guanidine deprotonates anthrones $\mathbf{2 0}$ or $\mathbf{2 1}$ and forms chiral ion pairs. Primary products of the ion pair complexes are the Diels-Alder adducts that may be further transformed in a base catalyzed retro-aldol reaction.

$[4+2]$-cycloaddition of the deprotonated anthrone. Michael products were shown to be secondary products of a base-catalyzed retro-aldol reaction and they are not converted backwards into Diels-Alder adducts under such conditions $[19,25,26]$. Our results shown below give further support to this view. Riant, Kagan and Ricard have demonstrated for the first time that deprotonated anthrones may coordinate to chiral counterions in less polar solvents. Up to $61 \%$ ee could be obtained using cinchona alkaloids as catalysts [26]. The subsequent work of Tan and co-workers with guanidine catalyst 8 achieved enantioselectivities as high as $99 \%$ ee [19]. In recent years functionalized chiral amines have been successfully used as catalysts for anthrone maleimide cycloadditions [29-35]. In the presence of 10, dichloroanthrone 21 reacted with maleimides 22 and 23 to produce exclusively cycloadducts $\mathbf{2 6}$ and $\mathbf{2 7}$. In contrast, a mixture of $\mathbf{2 5}$ and $\mathbf{2 8}$ resulted from the reaction of anthrone $\mathbf{2 0}$ and $\mathrm{N}$-phenylmaleimide (22). For the remaining combinations $(\mathbf{2 0}+$ 23; $20+24 ; 21+24)$ only the Michael products 29-31 could be observed $\left(0.1\right.$ equiv of $\left.\mathbf{1 0}, \mathrm{CH}_{2} \mathrm{Cl}_{2},-15^{\circ} \mathrm{C}\right)$.

To determine the enantioselectivity of guanidine $\mathbf{1 0}$ we started with the structurally simplest case, the reaction of anthrone $\mathbf{2 0}$ and $N$-phenylmaleimide (22) which finally turned out to be the most complex one (Table 1). The best but still low ee values for cycloadduct 25 were obtained in $\mathrm{CHCl}_{3}\left(37 \%\right.$ ee) and $\mathrm{CH}_{2} \mathrm{Cl}_{2}$ $(34 \%$ ee). Much better enantioselectivities of the Michael prod- uct $\mathbf{2 8}$ were found for reactions in solvents of increased polarity. Assuming that $\mathbf{2 8}$ is formed from $\mathbf{2 5}$ in a retro-aldol step, one might expect similar ee values for both compounds. This is clearly not the case. In THF the $83 \%$ ee for compound $\mathbf{2 8}$ strongly deviates from the low value for $\mathbf{2 5}$ ( $6 \%$ ee). Obviously, in the reaction of $\mathbf{2 0}$ and 22, a Diels-Alder step with low to moderate stereoselectivity is superimposed with a kinetic resolution of enantiomers in the subsequent retro-aldol reaction. Both are catalyzed by the chiral guanidine 10. As a result, the numbers shown in Table 1 are not constant but depend on the relative turnover of each reaction.

Table 1: Reaction of anthrone 20 and $N$-phenylmaleimide (22) in different solvents. $^{a}$

\begin{tabular}{|c|c|c|c|c|}
\hline \multirow[t]{2}{*}{ solvent } & \multicolumn{2}{|c|}{ Diels-Alder product 25} & \multicolumn{2}{|c|}{ Michael product 28} \\
\hline & yield $^{b}$ & $e e^{c}$ & yield $^{b}$ & $e e^{c}$ \\
\hline toluene & $36 \%$ & $22 \%$ & $51 \%$ & $47 \%$ \\
\hline$\left(\mathrm{CH}_{2} \mathrm{Cl}\right)_{2}$ & $88 \%$ & $6 \%$ & $8 \%$ & $35 \%$ \\
\hline $\mathrm{CHCl}_{3}$ & $3 \%$ & $37 \%$ & $91 \%$ & $25 \%$ \\
\hline $\mathrm{CH}_{2} \mathrm{Cl}_{2}$ & $28 \%$ & $34 \%$ & $70 \%$ & $41 \%$ \\
\hline THF & $51 \%$ & $6 \%$ & $42 \%$ & $83 \%$ \\
\hline $\mathrm{CH}_{3} \mathrm{CN}$ & $15 \%$ & $1 \%$ & $53 \%$ & $74 \%$ \\
\hline
\end{tabular}

aAll reactions were carried out with 0.1 equiv of guanidine 10 for $64 \mathrm{~h}$ at $-15{ }^{\circ} \mathrm{C}$. b Isolated yields after chromatographic separation. 'Determined by HPLC on a chiral column. 
When rac-25 reacted with 0.1 equiv of $\mathbf{1 0}$ in THF at $-15{ }^{\circ} \mathrm{C}$, at $22 \%$ conversion ee values of $18 \%$ and $70 \%$ were found for compounds $\mathbf{2 5}$ and $\mathbf{2 8}$. The dominant isomer of Michael product $\mathbf{2 8}$ is shown below to be $R$ configurated which corresponds to the slower running peak in Figure 3B. The $R$ isomer of $\mathbf{2 8}$ is formed from the $S, S$ isomer of $\mathbf{2 5}$ with retention of configuration (Scheme 2). The change from $S$ to $R$ is caused by a change in the CIP priorities of the substituents. Thus the faster running smaller peak in Figure 3A must correspond to the $S, S$ enantiomer of 25. Assuming independent first order rate laws for the opening of the $S, S$ and $R, R$ enantiomers of $\mathbf{2 5}$, the best numerical fit is obtained for $k_{\mathrm{S}, \mathrm{S}} / k_{\mathrm{R}, \mathrm{R}} \approx 6.5$. When both steps, Diels-Alder and Michael reaction, are catalyzed by guanidine $\mathbf{1 0}$ in THF (see Table 1), at $45 \%$ conversion the $R$ isomer of $\mathbf{2 8}$ and the $R, R$ isomer of $\mathbf{2 5}$ are the dominant species. However, due to the faster reaction of $S, S-\mathbf{2 5}$ the numerical simulation shows that not the $R, R$ but the $S, S$ isomer is the preferred product of the Diels-Alder step with approximately $33 \%$ ee. This value comes close to the numbers obtained for the production of 26 (25\% ee; $30 \%$ ee in THF) and $27\left(28 \%\right.$ ee) in $\mathrm{CH}_{2} \mathrm{Cl}_{2}$ when no secondary conversion occurs. In contrast, when compound 21 reacts with 24 ring opening is so fast that no Diels-Alder product accumulates. Here the ee value of the Michael product $31(21 \%)$ must correspond to the stereoselectivity of the Diels-Alder step. Due to low stereoselectivities and fast retroaldol reactions guanidine $\mathbf{1 0}$ is not optimal for the preparation of Diels-Alder adducts.

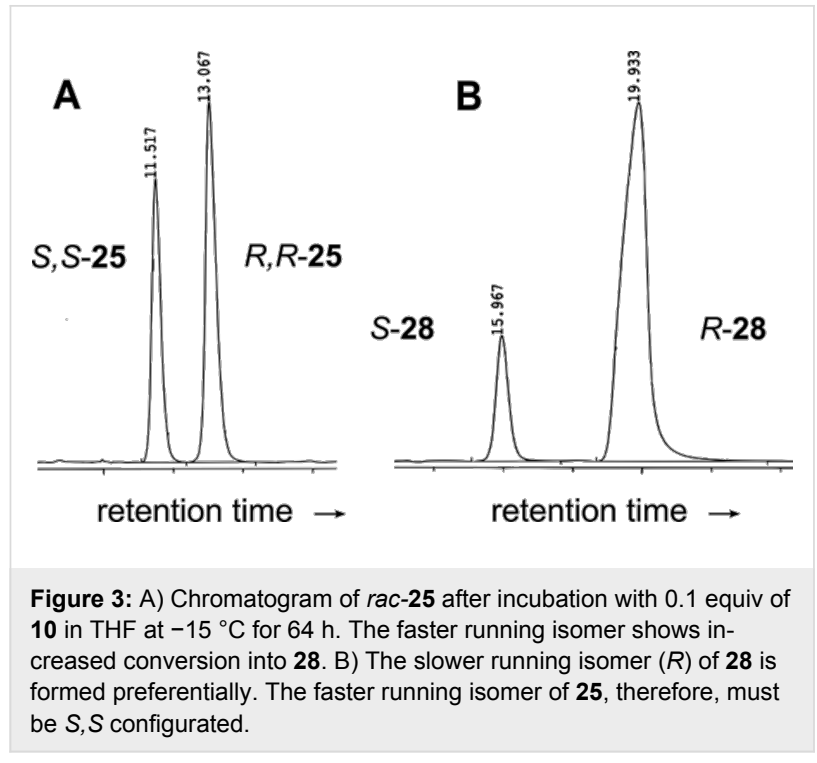

We therefore focussed our efforts on the Michael products: Anthrone $\mathbf{2 0}$ and maleimide 22 reacted with 0.1 equiv of $\mathbf{1 0}$ in THF at $-15{ }^{\circ} \mathrm{C}$ for $64 \mathrm{~h}$. Chromatographic separation then yielded $51 \%$ of $\mathbf{2 5}$ and $42 \%$ of Michael product $\mathbf{2 8}$ (83\% ee). Recrystallization afforded $32 \%$ of $\mathbf{2 8}$ with $99 \%$ ee. Thus,

$12.5 \mathrm{mg}$ of catalyst $\mathbf{1 0}$ produced $51 \mathrm{mg}$ of almost pure $R \mathbf{- 2 8}$. Analogous treatment of $\mathbf{2 0}$ and $\mathbf{2 3}$ yielded $21 \%$ of $\mathbf{2 9}$ (61\% ee). After recrystallization $15 \%$ of $\mathbf{2 9}$ with $98 \%$ ee were obtained. Finally, Michael product 30, obtained from 20 and 24 (42\%, $48 \%$ ee) yielded $26 \%$ of material with $95 \%$ ee.

Assignment of absolute configurations (Scheme 3): Well grown crystals of enantiopure Michael product 30 suitable for $\mathrm{X}$-ray structural analysis could be obtained by a second recrystallization from $\mathrm{CH}_{2} \mathrm{Cl}_{2}$ /cyclohexane. The 4-bromophenyl residue allowed us to assign the $R$ configuration by anomalous dispersion (Supporting Information File 4). This isomer corresponds to the slower running isomer on a Chiralpak IA column. By catalytic hydrogenation with Pd on charcoal the bromo residue of enantiopure $\mathbf{3 0}$ was replaced with hydrogen thus converting $R$ configurated 30 into $R$ configurated Michael product 28 (slower running isomer on Chiralpak IA and preferred product under catalysis with 10). Both compounds must result from the $S, S$ configurated Diels-Alder adducts. In the case of $\mathbf{2 5}$ this is the faster running isomer on Chiralpak IA. In an earlier

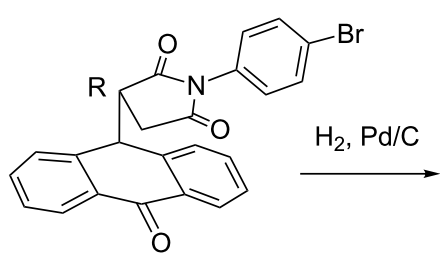

30 configuration assigned by anomalous dispersion $\uparrow \mathrm{Et}_{3} \mathrm{~N}, \mathrm{MeOH}$ $25^{\circ} \mathrm{C}, 1 \mathrm{~h}$

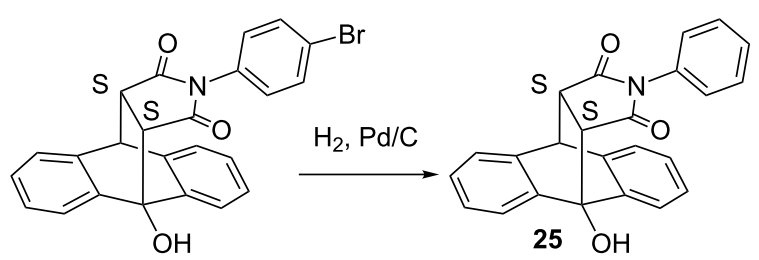

32 slower running isomer, consistent with ref. [28]

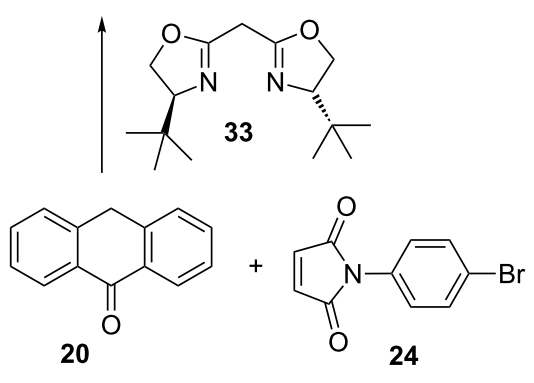

Scheme 3: Assignment of the absolute configurations by chemical correlation. The $R$ configuration of compound $\mathbf{3 0}$ is derived from the crystal structure. 
study [28] with bisoxazoline catalyst $\mathbf{3 3}$, we have assigned the $S, S$ configuration to the major isomer of product 32 . By hydrogenolysis, we could now convert such a sample $(40 \%$ ee) into 25. The product $S, S-\mathbf{2 5}$ was formed as the dominant product ( $35 \%$ ee) thus confirming our previous assignment. Under mild basic conditions, $S, S-32$ finally could be opened into $R$ configurated Michael product $30[25,26](31 \%$ ee) to generate a stereochemically consistent view.

\section{Conclusion}

(S)- $\beta$-Phenylalanine (13), readily accessible by enantioselective hydrolysis of ester $r a c-12$, is the starting material for an efficient synthesis of the chiral TBD analog $\mathbf{1 0}$. The cyclization steps in particular, which convert the triamine $\mathbf{1 9}$ into the final guanidine 10, give considerably higher yields compared to guanidines with five-membered rings such as compounds $\mathbf{6}-\mathbf{9}$. Apart from the better synthetic accessibility the formal ring expansion to the six-membered structure of $\mathbf{1 0}$ does not increase the stereoselectivity when it is used as a catalyst. We could not observe the near-perfect selectivities of the Tan catalyst $\mathbf{8}$ in the base-induced reaction of anthrones and maleimides. Nevertheless ee values of up to $83 \%$ for the formal Michael products allowed us to isolate 3 compounds in almost enantiopure form after a single recrystallization. The Tan guanidine 8 [19], the bisoxazoline 33 [28], and a stereochemically related bisamidine [27] consistently favor the $S, S$ isomer of Diels-Alder adduct 25. Although guanidine $\mathbf{1 0}$ has the opposite configuration, it also forms $S, S-25$ preferentially. Accordingly, transition-state structures in the reactions of guanidines $\mathbf{8}$ and $\mathbf{1 0}$ must differ from each other.

\section{Supporting Information}

\section{Supporting Information File 1}

Synthetic procedures, characterization data, copies of chromatograms on chiral columns and of ${ }^{1} \mathrm{H}$ and ${ }^{13} \mathrm{C}$ NMR spectra.

[http://www.beilstein-journals.org/bjoc/content/ supplementary/1860-5397-12-176-S1.pdf]

\section{Supporting Information File 2}

$\mathrm{X}$-ray data of guanidine $\mathbf{1 0}$ as benzoate salt (CCDC-1482611).

[http://www.beilstein-journals.org/bjoc/content/ supplementary/1860-5397-12-176-S2.cif]

\section{Supporting Information File 3}

X-ray data of compound 29 (CCDC-1482612). [http://www.beilstein-journals.org/bjoc/content/ supplementary/1860-5397-12-176-S3.cif]

\section{Supporting Information File 4}

X-ray data of compound 30 (CCDC-1482613).

[http://www.beilstein-journals.org/bjoc/content/ supplementary/1860-5397-12-176-S4.cif]

\section{References}

1. Ma, Y.; De, S.; Chen, C. Tetrahedron 2015, 71, 1145-1173. doi:10.1016/j.tet.2014.11.056

2. Ishikawa, T.; Kumamoto, T. Synthesis 2006, 737-752. doi:10.1055/s-2006-926325

3. Selig, P. Synthesis 2013, 45, 703-718. doi:10.1055/s-0032-1318154

4. McKay, A. F.; Kreling, M.-E. Can. J. Chem. 1957, 35, 1438-1445. doi:10.1139/v57-190

5. Schmidtchen, F. P. Chem. Ber. 1980, 113, 2175-2182. doi:10.1002/cber.19801130612

6. Echavarren, A.; Galán, A.; de Mendoza, J.; Salmerón, A.; Lehn, J.-M. Helv. Chim. Acta 1988, 71, 685-693. doi:10.1002/hlca.19880710402

7. Echavarren, A.; Galán, A.; Lehn, J.-M.; de Mendoza, J. J. Am. Chem. Soc. 1989, 111, 4994-4995. doi:10.1021/ja00195a071

8. Kurzmeier, H.; Schmidtchen, F. P. J. Org. Chem. 1990, 55, 3749-3755. doi:10.1021/jo00299a013

9. Jadhav, V. D.; Schmidtchen, F. P. J. Org. Chem. 2008, 73, 1077-1087. doi:10.1021/jo7021026

10. Turočkin, A.; Honeker, R.; Raven, W.; Selig, P. J. Org. Chem. 2016, 81, 4516-4529. doi:10.1021/acs.joc.6b00283

11. Davis, A. P.; Dempsey, K. J. Tetrahedron: Asymmetry 1995, 6, 2829-2840. doi:10.1016/0957-4166(95)00374-X

12. Kita, T.; Georgieva, A.; Hashimoto, Y.; Nakata, T.; Nagasawa, K. Angew. Chem., Int. Ed. 2002, 41, 2832-2834. doi:10.1002/1521-3773(20020802)41:15<2832::AID-ANIE2832>3.0.CO ;2-Q

13. Kita, T.; Shin, B.; Hashimoto, Y.; Nagasawa, K. Heterocycles 2007, 73, 241-247. doi:10.3987/COM-07-S(U)49

14. Khuong-Huu, F.; Le Forestier, J.-P.; Goutarel, R. Tetrahedron 1972, 28, 5207-5220. doi:10.1016/S0040-4020(01)88940-7

15. Büchi, G.; Rodriguez, A. D.; Yakushijin, K. J. Org. Chem. 1989, 54, 4494-4496. doi:10.1021/jo00280a009

16. Corey, E. J.; Ohtani, M. Tetrahedron Lett. 1989, 30, 5227-5230. doi:10.1016/S0040-4039(01)93748-7

17. Corey, E. J.; Grogan, M. J. Org. Lett. 1999, 1, 157-160. doi:10.1021/ol990623l

18. Ye, W.; Leow, D.; Goh, S. L. M.; Tan, C.-T.; Chian, C.-H.; Tan, C.-H. Tetrahedron Lett. 2006, 47, 1007-1010. doi:10.1016/j.tetlet.2005.11.133

19. Shen, J.; Nguyen, T. T.; Goh, Y.-P.; Ye, W.; Fu, X.; Xu, J.; Tan, C.-H. J. Am. Chem. Soc. 2006, 128, 13692-13693. doi:10.1021/ja064636n

20. Rodionow, W. M.; Postovskaja, E. A. J. Am. Chem. Soc. 1929, 51 , 841-847. doi:10.1021/ja01378a027

21. Rodionow, W. M. J. Am. Chem. Soc. 1929, 51, 847-852. doi:10.1021/ja01378a028

22. Faulconbridge, S. J.; Holt, K. E.; Garcia Sevillano, L.; Lock, C. J.; Tiffin, P. D.; Tremayne, N.; Winter, S. Tetrahedron Lett. 2000, 41, 2679-2681. doi:10.1016/S0040-4039(00)00222-7

23. Tasnádi, G.; Forró, E.; Fülöp, F. Tetrahedron: Asymmetry 2008, 19, 2072-2077. doi:10.1016/j.tetasy.2008.08.009 
24. Grayson, J. I.; Roos, J.; Osswald, S. Org. Process Res. Dev. 2011, 15 , 1201-1206. doi:10.1021/op200084g

25. Koerner, M.; Rickborn, B. J. Org. Chem. 1990, 55, 2662-2672. doi:10.1021/jo00296a024

26. Riant, O.; Kagan, H. B.; Ricard, L. Tetrahedron 1994, 50, 4543-4554. doi:10.1016/S0040-4020(01)89385-6

27. Akalay, D.; Dürner, G.; Bats, J. W.; Göbel, M. W. Beilstein J. Org. Chem. 2008, 4, No. 28. doi:10.3762/bjoc.4.28

28. Akalay, D.; Dürner, G.; Göbel, M. W. Eur. J. Org. Chem. 2008, 2365-2368. doi:10.1002/ejoc.200800179

29. Uemae, K.; Masuda, S.; Yamamoto, Y. J. Chem. Soc., Perkin Trans. 1 2001, 1002-1006. doi:10.1039/b100961n

30. Hau, C.-K.; He, H.; Lee, A. W. M.; Chik, D. T. W.; Cai, Z.; Wong, H. N. C. Tetrahedron 2010, 66, 9860-9874. doi:10.1016/j.tet.2010.10.064

31. Zea, A.; Valerao, G.; Alba, A.-N. R.; Moyano, A.; Rios, R. Adv. Synth. Catal. 2010, 352, 1102-1106. doi:10.1002/adsc.201000031

32. Zea, A.; Alba, A.-N. R.; Bravo, N.; Moyano, A.; Rios, R. Tetrahedron 2011, 67, 2513-2529. doi:10.1016/j.tet.2011.02.032

33. Bai, J.-F.; Guo, Y.-L.; Peng, L.; Jia, L.-N.; Xu, X.-Y.; Wang, L.-X. Tetrahedron 2013, 69, 1229-1233. doi:10.1016/j.tet.2012.11.011

34. Kumagai, J.; Otsuki, T.; Reddy, U. V. S.; Kohari, Y.; Seki, C.; Uwai, K.; Okuyama, Y.; Kwon, E.; Tokiwa, M.; Takeshita, M.; Nakano, H. Tetrahedron: Asymmetry 2015, 26, 1423-1429. doi:10.1016/j.tetasy.2015.10.022

35. Tawde, T. S.; Wagh, S. J.; Sapre, J. V.; Khose, V. N.; Badani, P. M.; Karnik, A. V. Tetrahedron: Asymmetry 2016, 27, 130-135. doi:10.1016/j.tetasy.2016.01.002

\section{License and Terms}

This is an Open Access article under the terms of the Creative Commons Attribution License (http://creativecommons.org/licenses/by/4.0), which permits unrestricted use, distribution, and reproduction in any medium, provided the original work is properly cited.

The license is subject to the Beilstein Journal of Organic Chemistry terms and conditions:

(http://www.beilstein-journals.org/bjoc)

The definitive version of this article is the electronic one which can be found at: doi:10.3762/bjoc.12.176 